\title{
FEATURES OF STANDARDIZATION AND REGISTRATION OF DIETARY SUPPLEMENTS COMPARED TO DRUGS
}

\author{
O. Bevz, O. Kryvanych, A. Fedosov, I. Sych, L. Perekhoda
}

\begin{abstract}
Постійне зростання кількості дієтичних добавок та попиту на них, а також прогресування самолікування з використанням безрецептурних лікарських засобів викликає питання щодо їх ефективності, безпеки та біоеквівалентності. Виникають питання також до критерїв, щуо висуваються до складових, виробництва, стандартизації та реєстраџіï готових лікарських засобів та дієтичних добавок.

Мета. Метою роботи є узагальнення відомостей щзодо особливостей стандартизації, сертифікації та реєстрачії дієтичних добавок у порівнянні з готовими лікарськими засобами на території Украӥни.

Матеріали і методи. Для виконання досліджень використано збір та аналіз даних, наведених у сучасній
\end{abstract} науковій літературі та документах регуляторних органів.

Результати. Здійснення виробництва, стандартизації та обігу готових лікарських засобів та дієтичних добавок відбувається відповідно до чинного законодавства Украӥни, міжнародних стандартів (ISO, ICH, GxP) і вимог Державної Фармакопеї Украӥни. Відповідно до цих документів, вимоги до якості лікарських препаратів та дієтичних добавок вирізняються, проте на відміну від десятирічної давнини, на сьогоднішній день можна спостерігати посилення регулювання та контролю зі сторони держави та правоохоронних органів щุодо усунення випадків фальсифікаиії та обігу незареєстрованних засобів.

Чинне законодавство Украӥни, щчо регулює виробництво, якість та обіг готових лікарських засобів гармонізоване з СС, висуває вимоги для забезпечення населення якісними імпортними / вітчизняними лікарськими препаратами. Щодо дієтичних добавок, то розпочалась прочедура гармонізації законодавства України з СС, щзо в майбутньому має призвести до покращення якості цүих засобів та підвищенню контролю зі сторони держави.

Обговорення. Узагальнені вимоги до особливостей стандартизаиії та реєстраиії дієтичних добавок на території Украӥни, яку необхідно дотримуватись при виготовленні, проведенні контролю якості, реєстрачї̈ та реалізаиї дієтичних добавок.

Висновки. Простіші умови реєстрації, реалізації і ширшого ринку збуту (система багаторівневого маркетингу, мережа Інтернет) призводять до стрімкого збільшення виробничтва дієтичних добавок в Україні та їх імпорту. Узагальнені відомості щодо вимог, які висуваються до якості дієтичних добавок у порівнянні з готовими лікарськими засобами, та особливостей їх реєстрації на територї Украӥни згідно чинного законодавства

Ключові слова: стандартизачія, реєстрачія, якість, готові лікарські засоби, дієтичні добавки, законодавство Украӥни

Copyright (C) 2019, O. Bevz, O. Kryvanych, A. Fedosov, I. Sych, L. Perekhoda. This is an open access article under the CC BY license (http://creativecommons.org/licenses/by/4.0).

\section{Introduction}

The current disease treatment strategy is characterized by systematic nature and involves the implementation of effective and safe complex therapy, which necessarily includes pharmacotherapy. Rational pharmacotherapy, as defined by the World Health Organization (WHO), involves the use of drugs in which the patient receives high-quality remedies appropriate to the clinical situation, at the required dose and at the lowest cost to the patient and the government [1].

A characteristic feature of the modern Ukrainian pharmaceutical market is the saturation of mainly nonoriginal drugs, and already known medicines, which are hidden by different trade names - generics, as well as dietary supplements, which provide for the prevention of diseases and are an additional source of biologically active substances.
Both medicines with well-studied medical use and traditional finished pharmaceutical products (FPP) and dietary supplements (DS) are in the category of over-thecounter medications and are used at the stage of pre-care for symptomatic therapy and to improve the quality of life of the patient. State registration of medicinal products is regulated by a number of legislative acts, decrees, instructions and orders, while the registration of dietary supplements in the territory of Ukraine is equivalent to the registration of food supplements and is regulated only by a few legal documents. Therefore, there are a number of issues that still need to be addressed to improve the quality of DS and FPP in order to provide the population with effective and equivalent drugs.

According to the Order of the Ministry of Health of Ukraine No. 876, as of 2019, 2961 OTC drugs were registered in the State Register of Medicinal Products of 
Ukraine, which is 129 points less than were registered in the previous year; most of the products removed from the register were included in dietary supplements. The most popular dietary supplements are vitamin or mineral supplements $(43 \%)$ followed by special supplements $(20 \%)$, herbal remedies $(20 \%)$ and sports nutrition (16\%) [2].

The current stage of development of the pharmaceutical market of Ukraine is characterized, on the one hand, by the increasing development of non-state forms of ownership, on the other - by the effective use of state regulation and control. For Ukraine, as in many countries in the world, the pharmaceutical market is a driving force for improving the health of the nation and a promising business area. Ukraine has all the conditions for the pharmaceutical market to develop and provide the population with high quality DS and FPP [3].

According to the Law of Ukraine "About Medicines", the term medicinal product includes substances or mixtures of natural, synthetic or biotechnological origin that are used to prevent pregnancy, prevention, diagnosis and treatment of human diseases or changes in the state and functions of the body. Medicinal products include active pharmaceutical ingredients (active substances), finished parmaceutical products (medicines, drugs), homeopathic remedies, agents used to identify pathogens, and control of pathogens or parasites, medicinal cosmetics and dietary supplements to food.

Finished parmaceutical products (medicines, drugs) - dosed drugs in the form and condition in which they are used, which have passed all stages of production (manufacture), including final packaging.

According to the Order of the Ministry of Health of Ukraine dated 19.12.2013 No. 1114 "On Approval of Hygienic Requirements for Dietary Supplements" in article I. In the general guidelines state - "Dietary supplements may contain a wide range of nutrients and other ingredients, including vitamins, minerals, amino acids, essential fatty acids, fiber, various herbs and herb extracts" [4]. However, unlike drugs, DS are available as a solid, mild or liquid dosage form for oral use only, and are intended for therapeutic nutrition, health promotion and as an additional component of diet [5].

There are a number of products that include the same components, but some are implemented as FPP and the other as DS. We faced with the question of comparing the features of DS standardization and certification versus FPP to determine the difference between their pharmacological action and biological equivalence.

\section{Planning (methodology) of research}

The research method is a comparative analysis of standardization, certification and registration of DS and FPP in Ukraine.

This required:

1. Analyze the legal framework governing standardization, certification, registration, circulation and control of drugs, FPPs and DS.

2. Analyze the features of DS application.

3. Identify the main stages of DS and FPP standardization and summarize the results.

4. Study and synthesize DS registration procedures against FPP.

\section{Materials and methods}

The basic legislative act regulating the quality control of drugs in Ukraine at all stages of production, sale, storage, etc. is the Law of Ukraine "On Medicines" [6], however, 41 legislative documents (laws, regulations, resolutions, acts) are presented on the website of the State Drug Service of Ukraine, relating to all stages of the life cycle of a drug, from synthesis, preclinical and clinical research, production to control and postmarketing research.

The document regulating the state registration / re-registration of medicinal products is the Decree of the Cabinet of Ministers of Ukraine "On approval of the procedure for state registration (re-registration) of medicinal products and the amount of fees for their state registration (re-registration)" [7].

Unlike drugs, the quality of dietary supplements is regulated by food law [8]: the Law of Ukraine "On Basic Principles and Requirements for Food Safety and Quality", the Law of Ukraine "On Consumer Information on Foodstuffs, the Order", "On Approval of the Regulation on Food the State Sanitary and Epidemiological Service of the Security Service of Ukraine", the Decree of the Ministry of Health of Ukraine on "Hygienic Requirements for Dietary Supplements", and the Law of Ukraine "About Food Information For Consumers".

The main regulatory act under which the quality of drugs is controlled is the State Pharmacopoeia of Ukraine (SPhU), and the second edition includes a general article "Dietary Supplements", which is informative for quality control and components of DS $[9,10]$.

\section{Results of the research}

Dietary supplements are implemented through a multi-level marketing system or via the Internet and post, that's why it is virtually impossible to control product quality. According to the analysis of the legislative framework, legislation on the basic principles and requirements for food safety and quality (including DS) on the territory of Ukraine is in force, which manufacturers and distributors must follow during implementation, but there are no requirements and regulatory documents (quality control methods, standardized quality assurance techniques, etc.) for quality control ready for DS implementation [11].

Analysis of DS safety data showed that $[12,13]$ :

- they may contain highly active substances or no biologically active components at all;

- the information material does not provide complete information on the quantitative composition of all ingredients, including excipients;

- administration contraindications are often $a b-$ sence;

- no DS interaction data with drugs;

- in most cases there is no indication of the safety of use in pregnant women, the fetus and breastfeeding;

- there is no clear evidence of their effectiveness when used as proposed.

In 2010, the Concept of Development of the Ukrainian Healthcare Pharmaceutical Sector for 20112020 was approved, which defines measures based on which the efficiency and effectiveness of standards are ensured, requirements for each link of medicinal prod- 
ucts - pharmacological, chemical-pharmaceutical, technological and requirements for ensuring the reproducibility and invariability of the medicinal product during the storage and delivery of the medicinal product during storage and delivery to the patient.

The main objectives of the Concept are to determine the strategy of the pharmaceutical sector, which should ensure the proper level of quality and effectiveness of pharmacotherapy, promote health, increase life expectancy and quality of life of the entire population of Ukraine. However, in this concept nothing is mentioned about DS, although their number in pharmacy chains is increasing every day, for example, part of the vitamin, bacterial drugs, etc., in most countries of the world referred to DS. They are manufactured, including at pharmaceutical manufactures of Ukraine, and the requirements for them differ from the requirements for drugs $[13,14]$.

One of the indicators of quality is the efficacy and safety that is validated for pre-clinical and clinical trials for medicinal products, but as noted above, DS includes components that have an evidence base and are approved for use. The features of determining the efficacy and safety of drugs and DS in accordance with the current legislation of Ukraine were summarized and presented in Fig. 1.

After validation and establishment of efficiency and safety, quality control (QA), which should occur at all stages from synthesis, process, production, registration and control of finished products, is no less important.

QA of drugs in Ukraine are carried out in accordance with the requirements (monographs) of SPhU, international ISO standards and ICH guidelines, but the requirements for DS QA are made only in the general SPhU article and applicable regulations.

The methods proposed for QA of drugs must be accurate, sensitive, highly reproducible, i.e. validated or verified [15]. In order to prevent errors, calibrated and qualified utensils and equipment shall be used for testing and shall be carried out in premises meeting certain requirements [16-20].

The general data given in the current legislation of Ukraine regarding the quality requirements of DS compared to FPP, which must be checked during the QA are shown in Fig. 2.
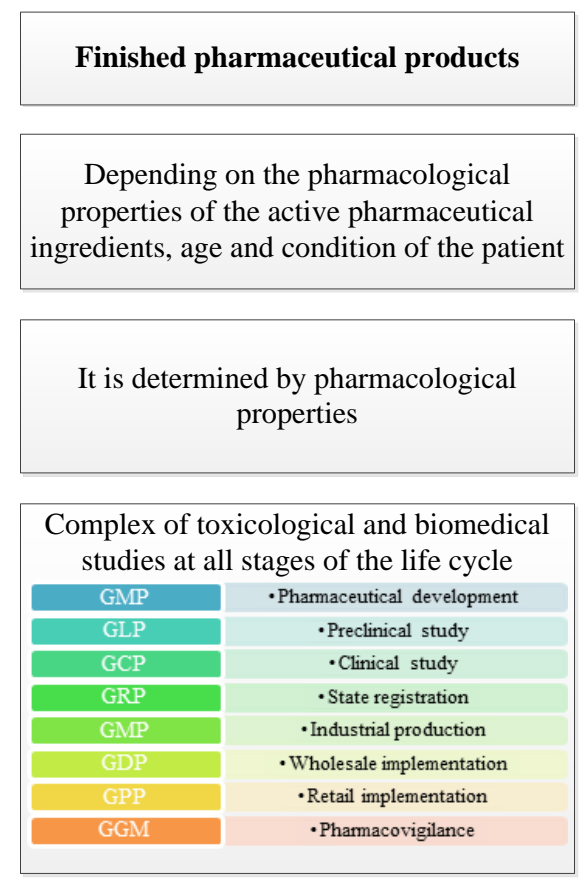

Dosage form, depending on the route of administration

(parenteral, sublingual, oral, etc.).
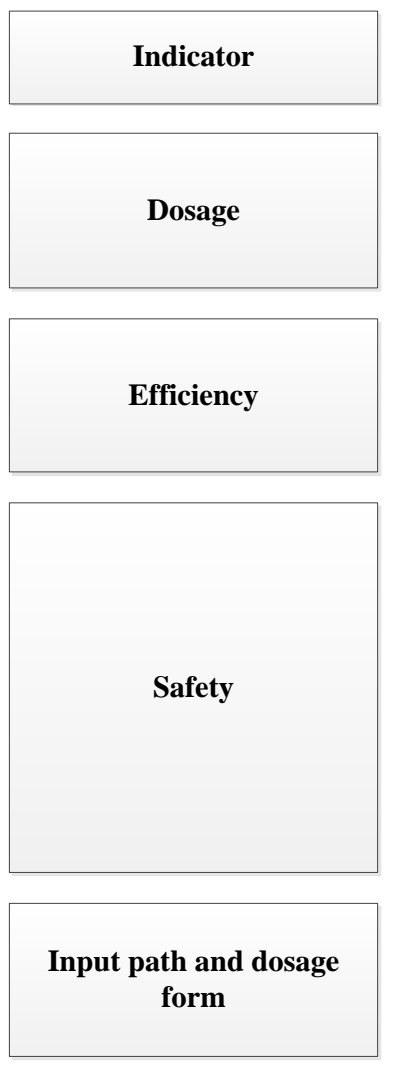

Dietary supplements

The daily doses of consumption are approved by the Chief Sanitary Doctor of

Ukraine, according to the legislation
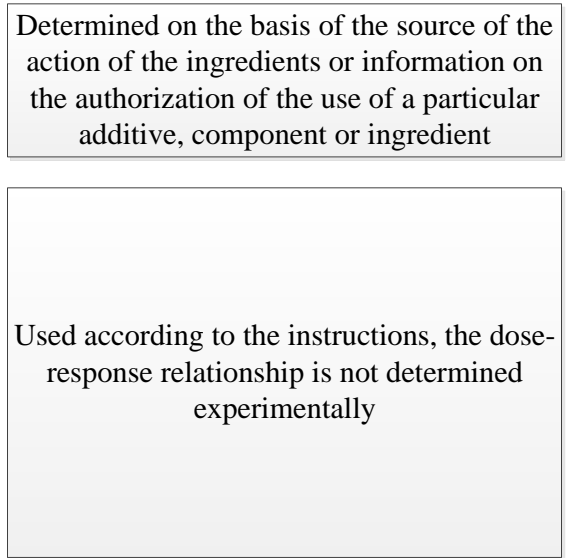

Solid, soft or liquid oral dosage forms

Fig. 1. Determining the effectiveness and safety of drugs and DS 


\begin{tabular}{|c|c|c|}
\hline Pharmaceutical drugs & & Dietary supplements \\
\hline $\begin{array}{l}\text { Appropriate methods, should be: } \\
\text { - Specificity; } \\
\text { - Accuracy; } \\
\text { - Reproducibility }\end{array}$ & 氕 & $\begin{array}{l}\text { Appropriate methods are used to } \\
\text { confirm the conformity of } \\
\text { organoleptic, biological, physical } \\
\text { and chemical parameters and } \\
\text { properties, which specific to this } \\
\text { type of dietary product, those } \\
\text { parameters and properties that are } \\
\text { indicated on the label. }\end{array}$ \\
\hline $\begin{array}{l}\text { Determination of impurities with } \\
\text { their limits }[18,19] \text { : } \\
\text { - organic / inorganic/solvents, } \\
\text { - known / potential, } \\
\text { - specific / non-specific }\end{array}$ & \multirow{4}{*}{$\stackrel{n}{\mathscr{E}}$} & $\begin{array}{l}\text { The content of heavy metals } \\
\text { (maximum levels, mg / kg): lead - 3.0, } \\
\text { cadmium - 1.0 (DS, produced from marine } \\
\text { organisms - 3.0), mercury - } 0.1 \text { [17] }\end{array}$ \\
\hline $\begin{array}{c}\text { "Dissolution" for pharmaceutical } \\
\text { drugs }\end{array}$ & & "Microbial limit test" \\
\hline $\begin{array}{c}\text { "Uniformity of dosage units" for } \\
\text { pharmaceutical drugs }\end{array}$ & & Residual pesticides \\
\hline "Microbial limit test" & & Aflatoxins \\
\hline $\begin{array}{l}\text { Methods of quantitative } \\
\text { determination of APIs and } \\
\text { excipients, which proved [20]: } \\
\text { - Correctness (accuracy); } \\
\text { - Precision (convergence); } \\
\text { - Specificity; } \\
\text { - Linearity; } \\
\text { - Detection limit range }\end{array}$ & 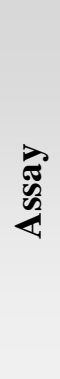 & $\begin{array}{l}\text { Carry out a quantitative } \\
\text { determination by similar methods for } \\
\text { individual groups of active } \\
\text { ingredients }\end{array}$ \\
\hline
\end{tabular}

Fig. 2. Indicators that are taken into account when developing FPP and DS quality control techniques

The DS safety and quality profile is used to protect the life and health of the population from the harmful factors that may be present in DS components [21]. In terms of FPP quality, efficiency and safety, it is a complete set of measures that control the whole "life cycle" from production to the expiration date of all indicators (identification, purity, quantification and release of the active substance).

\section{Discussion of the results}

In accordance with the requirements for efficiency and safety, as well as the indicators taken into account in the standardization of quality control procedures, registration takes place for DS and FPP by different organizations and by different procedures.

The Ukrainian legislation on state registration of medicinal products has in most respects been brought into line with EU law. Given that FPPs are exported to other countries of the world, or imported FPPs are undergoing the necessary registration procedure in Ukraine, the requirements for pharmaceutical products must comply with global standards regarding the requirements for components, process and conditions of manufacture, quality, safety and efficiency testing, and packaging mark [22]. To register FPP, you must submit an application to the Ministry of Health of Ukraine, to which is added a dossier consisting of five modules, including materials of preclinical, clinical study, process description and quality control methods, with the submission of validation or verification procedure documents. A prerequisite is that each FPP creation and implementation process is relevant to good pharmaceutical practices; report on evaluation of the EMA registration dossier and corresponding conclusion of the State Expert Centre of the Ministry of Health of Ukraine (Fig. 3) [23]. 


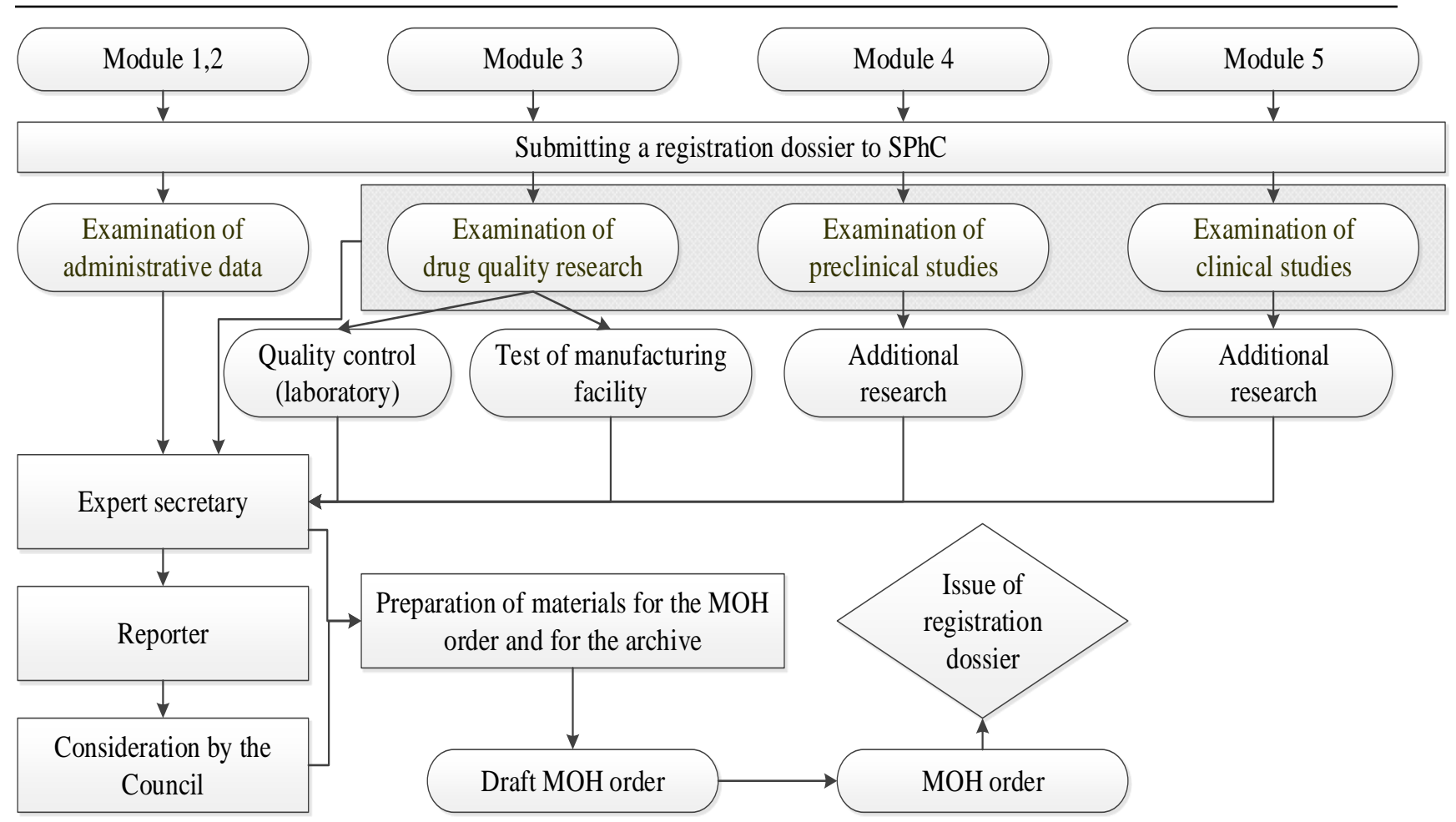

Fig. 3. FPP registration procedure in Ukraine

In turn, the DS registration process takes less time and paperwork. Only the application for the sanitary and epidemiological examination, the samples of the object, the recommendations for application and the instruction, as well as the specification indicating the DS components and their identification indicators are required. Documents certifying safety and quality, regulatory and veterinary approvals for products of animal origin shall also be added if available [24].

The procedure for DS registration in the territory of Ukraine according to the requirements of the Ministry of Health can be provided as follows (Fig. 4).

Thus, the Ministry of Health of Ukraine issues a registration certificate for the medicinal product, and the
State Service of Ukraine for Food Safety and Consumer Protection issues a conclusion of the state sanitary-expert examination, and in the presence of these documents the supplements are allowed for sale. However, the DS registration procedure is flawed, no documents are provided to confirm the quantitative content of the constituents in the composition, and the effects of the excipients or combination of ingredients are not verified in terms of pharmacological action and safety.

The question of dietary supplements that can be purchased via the Internet from abroad remains open, given that the turnover of these DS is not subject to state control. 


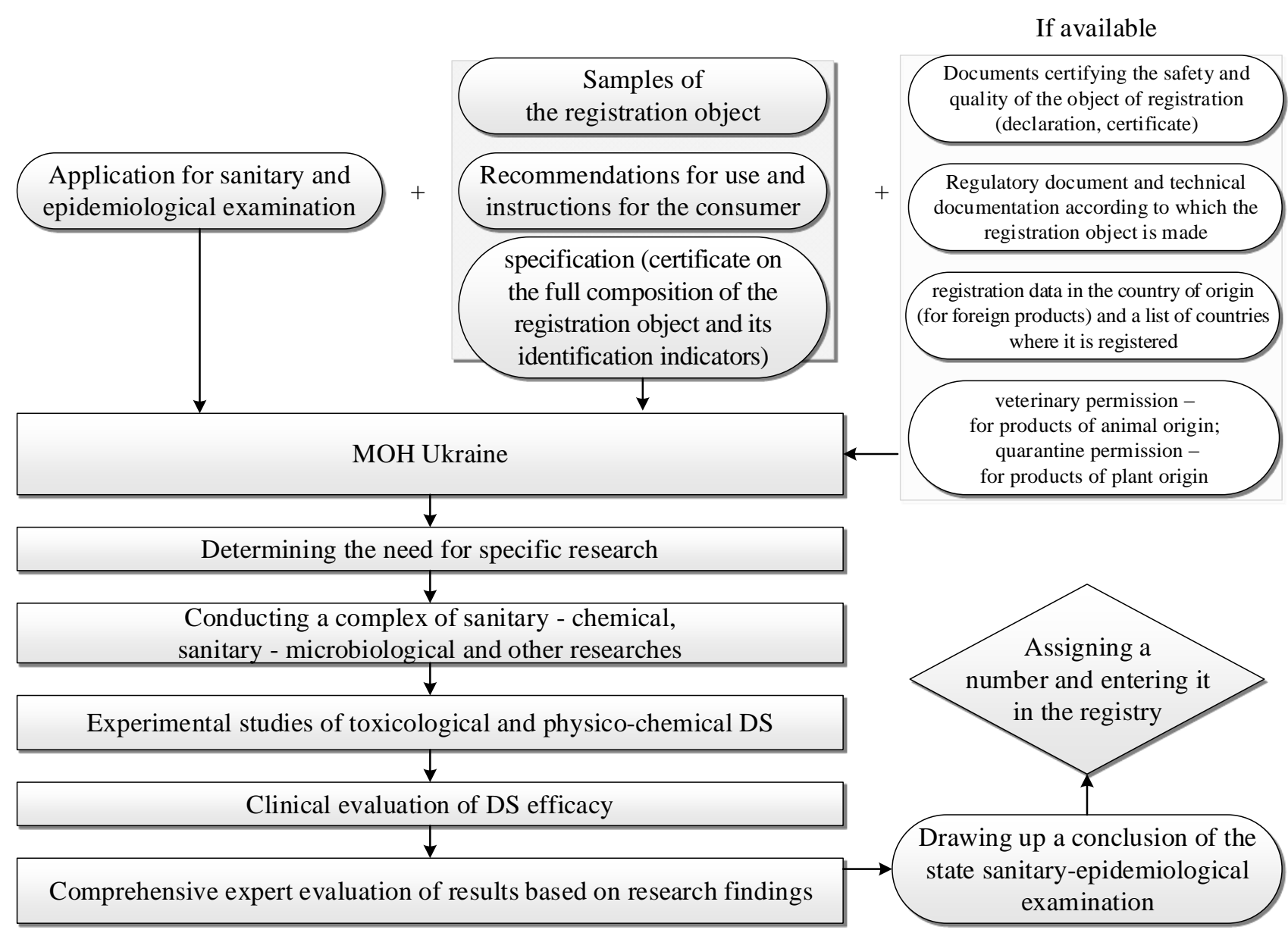

Fig. 4. DS registration procedure in the territory of Ukraine

\section{Conclusions}

The rapid increase in the production and import /export of DS and OTC FPPs has led to a revision of current Ukrainian legislation and the need to harmonize requirements with the EU. All this is a prerequisite for the need to fully carry out biomedical evalua tion, control of registration and the creation of a proper regulatory framework that would ensure the quality and safety of DS for consumers, given that both the composition and dosage of such products are now practically without expert evaluation.

\section{References}

1. Kucherenko, N., Gudzenko, A. (2017). The analysis of Ukrainian pharmaceutical market in the aspect of solid oral drugs with postponed action. ScienceRise: Pharmaceutical Science, 3 (7), 6-10. doi: http://doi.org/10.15587/2519-4852.2017.103327

2. Brown, A. C. (2017). An overview of herb and dietary supplement efficacy, safety and government regulations in the United States with suggested improvements. Part 1 of 5 series. Food and Chemical Toxicology, 107, 449-471. doi: http://doi.org/10.1016/ j.fct.2016.11.001

3. Vinnikova, I. I., Ponomarenko, I. V., Hrebnov, H. M. (2015). Vplyv polityko-pravovoho faktoru na reklamu likarskykh zasobiv. Ekonomichnyi visnyk NTUU "KPI", 12, 339-345.

4. Nemchenko, A. S., Mishchenko, V. I., Timofeiev, S. V., Vynnyk, O. V. (2017). Doslidzhennia vlastyvostei diietychnykh dobavok, likarskykh zasobiv ta kharchovykh dobavok v «piramidi zdorovia liudyny». Menedzhment ta marketynh u skladi suchasnoi ekonomiky, nauky, osvity, praktyky. Kharkiv, 380-381.

5. Pro udoskonalennia orhanizatsii likuvalnoho kharchuvannia ta roboty diietolohichnoi systemy v Ukraini (2013). Nakaz MOZ Ukrainy No. 931. 29.10.2013. Available at: https://zakon.rada.gov.ua/laws/show/z2205-13

6. Pro likarski zasoby (1996). Zakon Ukrainy No. 123/96-VR. 04.04.1996. Available at: http://zakon.rada.gov.ua/ laws/main/123/96- \%D0 \%B2 \%D1\%80

7. Pro zatverdzhennia Poriadku derzhavnoi reiestratsii (perereiestratsii) likarskykh zasobiv i rozmiriv zboru za yikh derzhavnu reiestratsiiu (perereiestratsiiu) (2005). Postanova Kabinetu Ministriv Ukrainy No. 376. 26.05.2005. Available at: http://zakon.rada.gov.ua/laws/show/376-2005- \%D0 \%BF

8. Hubin, Yu. I. (2019). Problemy yakosti diietychnykh dobavok. Upravlinnia yakistiu v farmatsii. Kharkiv: NFaU, $29-31$.

9. Derzhavna Farmakopeia Ukrainy. Vol. 1 (2015). Kharkiv: Derzhavne pidpryiemstvo «Ukrainskyi naukovyi farmakopeinyi tsentr yakosti likarskykh zasobiv», 1128. 
10. Derzhavna Farmakopeia Ukrainy. Vol. 3 (2014). Kharkiv: Derzhavne pidpryiemstvo «Ukrainskyi naukovyi farmakopeinyi tsentr yakosti likarskykh zasobiv», 732.

11. Kryzhanovska, A. V., Oproshanska, T. V. (2019). Kontrol yakosti diietychnykh dobavok. Upravlinnia yakistiu v farmatsii. Kharkiv: NFaU, 74.

12. Suprun, E. V. (2018). Lekarstva i biologicheski aktivnye dobavki: sovremennii vzgliad na ocenku sootnosheniia effektivnost/bezopasnost. Zdorov'ia Ukraini 21 storichchia, 3 (424). Available at: https://fp.com.ua/articles/lekarstva-y-byologycheskyaktyvnye-dobavky-sovremennyj-vzglyad-na-otsenku-sootnoshenyya-effektyvnost-bezopasnost/

13. Ostanina, N. V., Kuznetsova, O. M. (2013). Stvorennia dodatkovoho rozdilu «Diietychni dobavky» Derzhavnoi farmakopei Ukrainy - shliakh do zabezpechennia naselennia ukrainy yakisnoiu produktsiieiu. Farmatsevtychnyi zhurnal, 1, 16-20.

14. Pro zatverdzhennia Kontseptsii rozvytku farmatsevtychnoho sektoru haluzi okhorony zdorovia Ukrainy na 2011-2020 roky (2010). MOZ Ukrainy No. 769. 13.09.2010. Available at: https://zakon.rada.gov.ua/rada/show/v0769282-10

15. Grizodub, A. I. (2014). Standartizovannye procedury validacii metodik kontrolia kachestva LS. Farmaciia Kazakhstana, $12,18-25$.

16. Assuring the quality of test results. ORA LABORATORY PROCEDURE. Food and Drug Administration. Document No ORA - LAB 5.9. Available at: https://www.fda.gov/downloads/scienceresearch/fieldscience/laboratorymanual/ucm092168.pdf

17. Pro zatverdzhennia Derzhavnykh hihiienichnykh pravyl i norm "Rehlament maksymalnykh rivniv okremykh zabrudniuiuchykh rechovyn u kharchovykh produktakh" (2013). Nakaz MOZ Ukrainy No. 368. 13.05.2013. Available at: https://zakon.rada.gov.ua/laws/show/z0774-13

18. ICH Harmonized Tripartite Guideline: Q3A (R2) Impurities in new substances (2016). The international conference on harmonisation of technical requirements for registration of pharmaceuticals for human use (ICH), 15.

19. ICH Harmonized Tripartite Guideline: Q3B (R2) Impurities in new drug products (2006). The international conference on harmonisation of technical requirements for registration of pharmaceuticals for human use (ICH), 14.

20. Bevz, N., Georgiyants, V., Gryzodub, O. (2019). Algorithm for carrying out a procedure for verification of a spectrophotometric method for analysis of solid-dosed dosage forms according to the requirements of SPHU 2.0. ScienceRise: Pharmaceutical Science, 3 (19), 4-10. doi: http://doi.org/10.15587/2519-4852.2019.172046

21. Malinina, N., Yevtushenko, O. (2017). The Order of Circulation of Dietary Supplements that Contain Food Additives on Ukrainian Pharmaceutical Market. Path of Science, 3 (5), 4.1-4.6. doi: http://doi.org/10.22178/pos.22-4

22. Corby-Edwards, A. K. (2013). Regulation of Dietary Supplements. Congressional Research Service, 29. Available at: https://www.everycrsreport.com/files/20130506_R43062_114049f4d7a3ff8b80d37cffd2f432b95cad17a9.pdf

23. Yavorski, T., Tomashyk, M., Borkovski, L. et. al. (2016). Zvit shchodo vidpovidnosti protsedury derzhavnoi reiestratsii likarskykh zasobiv $\mathrm{v}$ Ukraini zakonodavstvu ta standartam YeS. Available at: https://moz.gov.ua/uploads/0/350ebrd_project_final_report_ukr_2016_11_30.pdf

24. Tymchenko, O. V., Kotov, A. H. (2018). Ohliad zakonodavchykh zmin u sferi zabezpechennia yakosti diietychnykh dobavok v Ukraini. Farmakom, 4, 15-24.

Received date 15.10.2019

Accepted date 17.11.2019

Published date 30.12.2019

Olena Bevz, PhD, Assistant, Department of Medicinal Chemistry, National University of Pharmacy, Pushkinska str., 53, Kharkiv, Ukraine, 61002

E-mail: bevz.helen@gmail.com

Olga Kryvanych, $\mathrm{PhD}$, Associate Professor, Department of Pharmaceutical Disciplines, Uzhhorod National University. Narodna sq., 3, Uzhhorod, Ukraine, 88000

E-mail: olgabevz87@gmail.com

Andrii Fedosov, Doctor of Pharmaceutical Sciences, Associate Professor, Chief Vice-Rector on Educational Work, Department of Medicinal Chemistry, National University of Pharmacy, Pushkinska str., 53, Kharkiv, Ukraine, 61002

E-mail: prorector1@nuph.edu.ua

Irina Sych, $\mathrm{PhD}$, Associate Professor, Department of Medicinal Chemistry, National University of Pharmacy Pushkinska str., 53, Kharkiv, Ukraine 61002

E-mail: irina777sych@gmail.com

Lina Perekhoda, Doctor of Pharmaceutical Sciences, Professor, Head of Department, Department of Medicinal Chemistry, National University of Pharmacy, Pushkinska str., 53, Kharkiv, Ukraine, 61002

E-mail: linaperekhoda@ukr.net 